\title{
OBSERVATION OF ABUNDANT NORTHERN LEOPARD FROGS AT WARGATIE LAKE, MANITOBA
}

Cary Hamel, Nature Conservancy of Canada, Manitoba Region, 200-611 Corydon Ave., Winnipeg, MB R3L OP3 Cary.Hamel@natureconservancy.ca

Melissa Grantham, Nature Conservancy of Canada, Manitoba Region, 200-611 Corydon Ave., Winnipeg, MB R3L OP3 Melissa.Grantham@natureconservancy.ca

\section{Conservation Status \& Local Abundance}

The northern leopard frog (Lithobates pipiens) is a Species of Special Concern in the prairie provinces. ${ }^{1}$ These frogs require three habitat types to complete their life cycle: terrestrial (uplands and native prairie) for summer foraging, wetlands for reproduction, and permanent water bodies that do not freeze solid for overwintering. Connectivity and close proximity among those habitats is especially important, due to the frogs' limited dispersal distance ${ }^{2}$

The species was once common enough to be commercially harvested ${ }^{1,4}$ Northern leopard frogs were particularly abundant in the southern marshes of Lake Winnipeg and Lake Manitoba, and were noted as being the most abundant frog in the Delta Marsh region in 1961 .2, In the 1970s, however, the species started dying off from an apparent illness; large numbers of dead frogs were observed, and they seemed to disappear from major population centres 1,4,6 $^{\text {The species }}$ started to recover in the 1990s, with local populations having recovered significantly since then. ${ }^{1}$ Northern leopard frogs are currently considered "apparently secure" in Manitoba.

Few quantified reports of leopard frog abundance in Manitoba are available. ${ }^{1,2}$ Reports from some observers suggest that they can be locally abundant. Manitoba Herps
Atlas observers have reported densities of frogs as high as 100 individuals per $100 \mathrm{~m}^{2}$ 6,7 Several (up to five to 10 in places) northern leopard frogs per metre of shoreline (considered "immense numbers") were reported at the Pinawa sewage lagoons in July 1990, which were similar to observations at a Weyburn, Saskatchewan golf course in July $2003^{7-9}$

\section{Study Area \& Methods}

Surveys occurred on a 65 ha parcel that is a component of the Nature Conservancy of Canada's Riding Mountain House conservation project near Keeseekoowenin, south of Riding Mountain National Park, Manitoba (Fig. 1). The property is characterized by Loamy lacustrine and Loamy till (well drained, slope 5-9\%, agricultural capability 3-4) soils and supports several pothole wetlands interspersed with annual cropland (wheat was grown in

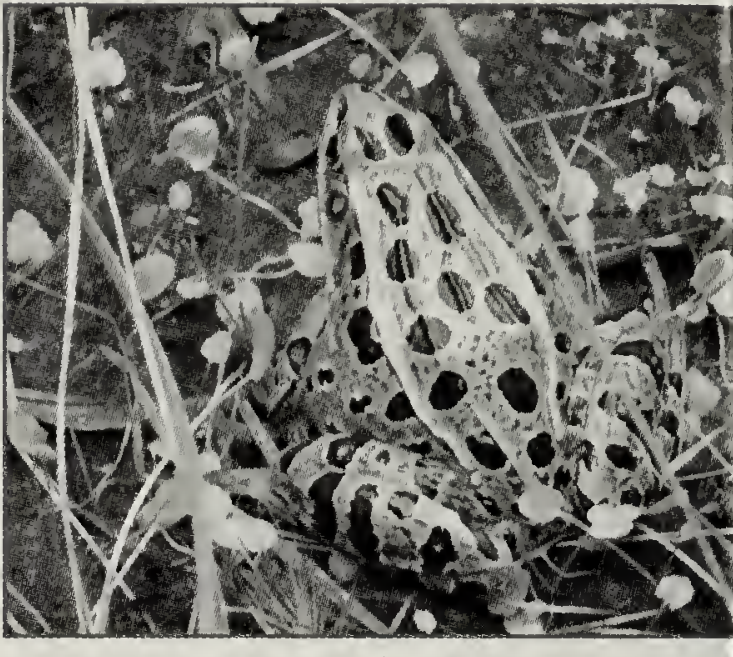

Photo credit Annie McLe

the season prior to surveys). ${ }^{10}$ The property lies adjacent to perennial grass pasture, hayland, wetlands, and Wargatie Lake. Annual cropland occurs within $800 \mathrm{~m}$ of the property and is characteristic of regional land use. Wargatie Lake is 160 ha large and $12 \mathrm{~m}$ deep ${ }^{11}$

While conducting vegetation surveys on September 8, 2011, Nature Conservancy of Canada staff (Cary Hamel, Julie Pelc, and Levi Newediuk) noted what appeared to be an exceptional abundance of presumed young-of-the-year norther leopard frogs. After investigating several portions of the property, the surveyors determined that abundanc appeared to be generally ubiquitous. In an attempt to quantify abundance

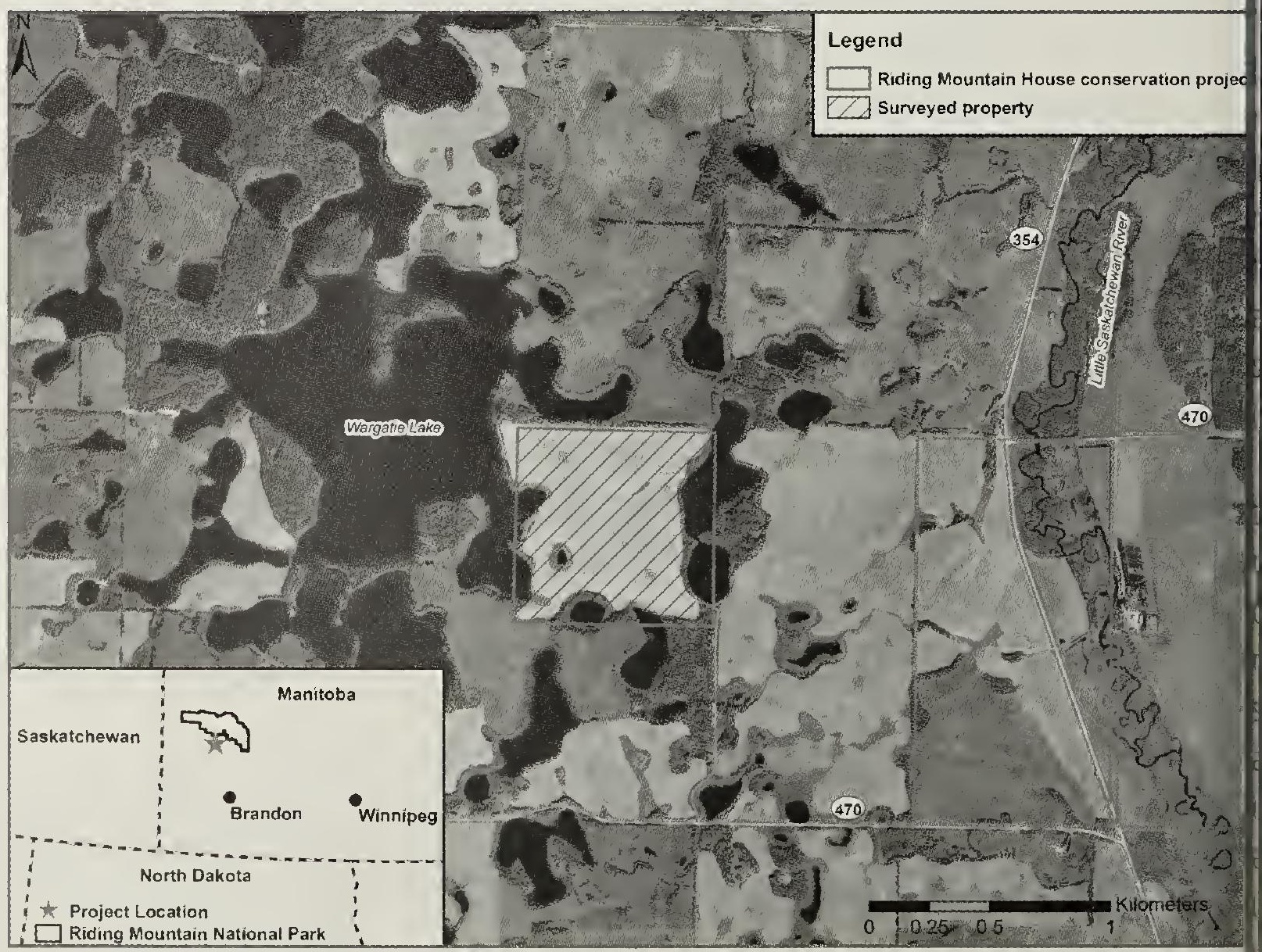

Figure 1: Map of the survey area, part of the Nature Conservancy of Canada's Riding Mountain Hou conservation project near Keeseekoowenin, south of Riding Mountain National Park, Manitol 
ix transects were established through pland areas of the property, running oughly perpendicular to Wargatie ake. Surveyors attempted to make ransects as straight as possible and oughly $100 \mathrm{~m}$ in length; however, ctual transect length varied from 111 o $145 \mathrm{~m}$. The beginning and end of ach transect was noted using a GPS. he flushing distance of frogs was letermined to be approximately $1 \mathrm{~m}$. urveyors noted the number of frogs bserved while walking transects. Veather conditions were sunny and pproximately 21 degrees Celsius.

\section{Results}

Four hundred and forty-two frogs vere observed along $780 \mathrm{~m}$ travelled Table 1). Based on a $1 \mathrm{~m}$ flushing istance, transects were considered be $2 \mathrm{~m}$ wide belts. The average lensity of surveyed frogs was 0.29 rogs $/ \mathrm{m}^{2}$, or 2,900 frogs per ha.

\section{piscussion}

While our sample size was very nall, the limited number of reported stimates of northern leopard frog bundance in Manitoba makes hese observations noteworthy. Our bservations appear similar to the mmense' numbers reported by Taylor and references therein). ${ }^{8}$ The authors cognize that survivorship between fe stages varies (see Kinney 2011 for cview) and it is unknown how many ogs survived to overwinter. ${ }^{12}$ Frog bundance was notably higher at the urvey location earlier in the season evi Newediuk, pers. comm.).

Pope et al. (2000) summarize he landscape scale considerations quired to support a metapopulation f northern leopard frogs, and their sults suggest that full landscape ructure, including breeding habitat 5 well as complementary habitat, linked to frog abundance. ${ }^{13}$ The djacency of relatively deep Wargatie ake as overwintering habitat ay contribute to the observed bundances.

Table 1. Northern leopard frogs observed along six transects at the Nature Conservancy of Canada's Riding Mountain House conservation project in September 2011.

\begin{tabular}{|l|l|l|l|}
\hline TRANSECT & $\begin{array}{l}\text { TRANSECT } \\
\text { LENGTH (M) }\end{array}$ & $\begin{array}{l}\text { \# NORTHERN LEOPARD } \\
\text { FROGS OBSERVED }\end{array}$ & $\begin{array}{l}\text { \# NORTHERN } \\
\text { LEOPARD FROGS/M² }\end{array}$ \\
\hline 1 & 111 & 85 & 0.383 \\
2 & 119 & 89 & 0.374 \\
3 & 145 & 71 & 0.245 \\
4 & 130 & 69 & 0.265 \\
5 & 145 & 45 & 0.155 \\
6 & 130 & 83 & 0.319 \\
\hline
\end{tabular}

Post survey (October 2011), portions of the annual cropland on the surveyed property were restored. Ten pothole wetlands ranging in size from 0.09 to 1.10 ha in size and encompassing 3.8 ha in total were recreated. A post-restoration examination of northern leopard frog abundance represents an interesting research opportunity.

\section{Acknowledgements}

Julie Pelc and Levi Newediuk provided field assistance. Jean Rosset and Jordan Becker provided site information. Funding for NCC's conservation work at Wargatie Lake was supported by the Government of Canada's Natural Areas Conservation Program, the U.S Fish and Wildlife Service, and the Province of Manitoba.

\section{COSEWIC (2009) COSEWIC assessment} and update status report on the Northern Leopard Frog Rana pipiens, Rocky Mountain Population, Western Boreal/Prairie Population and Eastern populations, In Canada. Committee on the Status of Endangered Wildlife in Canada. Ottawa. Vii + 69 pp. (www.sararegistry.gc.ca/status/status_e.cfm).

2. Environment Canada (2013) Management Plan for the Northern Leopard Frog (Lithobates pipiens), Western Boreal/Prairie Populations, in Canada. Species at Risk Act Management Plan Series. Environment Canada, Ottawa. iii +28 pp.

3. NatureServe (2015) NatureServe Explorer: An online encyclopedia of life [web application]. Version 7.1. NatureServe, Arlington, Virginia. Available http://explorer.natureserve.org. (Accessed: April 23, 2015).

4. Koonz W (1992) Amphibians in Manitoba. In Bishop CA, Pettit KE (eds) Declines in Canadian Amphibian Populations: Designing and national monitoring strategy. Canadian Wildlife Service, Occasional Paper No. 76:1920.
5. Tamsitt JR (1961) Notes on the herpetofauna of the Delta Marsh of Lake Manitoba, Canada. The Canadian-Field Naturalist 75:149-151.

6. Nature North (2015a) Amphibians of Manitoba: Leopard Frog. Available from wuw. naturenorth.com/1np/Species/ amphibian/1Ffrle.html. (Accessed: April 22, 2015).

7. Nature North (2015b) Manitoba Herps Atlas Interactive Database. Available from unw. naturenorth.com/Herps/MHA_Data.html (Accessed: April 22, 2015).

8. Taylor P (2005) Calling Periods for frogs and toads near Pinawa, Manitoba, with an update on Mink Frog and Green Frog distribution. Blue Jay 64(1):44-55.

9. Bailey M (2004) Northern leopard frogs in a golf course water hazard. Blue Jay 62(1):4345.

10. Western Land Resource Group - Agriculture and Agri-Food Canada (2002) Rural Municipality of Park - Soil. Soils and Terrain 98-10. Winnipeg.

11. Manitoba Conservation. Wargatie Lake Manitoba [Map]. One Thousand Metre Universal Transverse Mercator Grid. Canada Map Sales, 2006.

12. Kinney VC (2011) Adult survivorship and juvenile recruitment in populations of Crawfish Frogs (Lithobates areolatus), with additional consideration of the population sizes of associated pond breeding species. MSc Thesis. Indiana State University, Terre Haute, Indiana.

13. Pope SE, Fahrig L, and Gray Merriam H (2000) Landscape complementation and metapopulation effects on leopard frog populations. Ecology 81(9):2498-2508. 